\title{
„VRATIT ĆEMO NARODU DRŽAVU” - DESNI POPULIZAM, NACIONALIZAM I NOVI IZAZOVI
}

\author{
Nenad Miščević \\ Sveučilište u Mariboru \\ Central European University
}

\begin{abstract}
SAŽETAK ${ }^{1}$
Tema rada je desni populizam, vrlo jak i raširen na cijeloj sjevernoj polutki; ovdje nas zanima naša zemlja i njoj najbliže. Najprije općenito karakteriziramo populizam, a onda razmatramo njegov odnos s najbližim mu pojavama, nacionalizmom i patriotizmom. Zanimljiv je fenomen u Hrvatskoj odsutnost snažnih jasno populističkih stranki usprkos snažnoj nacionalističkoj orijentaciji u izbornoj bazi; najjednostavnije je objašnjenje da je HDZ uspio preuzeti važne teme desnog populizma, a ipak sačuvati formu i ideologiju parlamentarne demokracije. Koliko je to rješenje stabilno vidjet će se u budućnosti. Uspon populizma promijenio je okvir političkih dilema kod nas i u svijetu; zastupnici suprotnih stajališta sada moraju ponovno promisliti pretpostavke na kojima djeluju i ponuditi nova rješenja.
\end{abstract}

KLJUČNE RIJEČI: populizam, patriotizam, nacional-populizam, politički rascjepi

\section{Kontakt autora:}

Nenad Miščević, redovni profesor, Filozofska fakulteta Univerze v Mariboru, Koroška cesta 160, 2000 Maribor.

E-pošta: vismiscevic@ceu.edu

1 Tekst se u velikom dijelu oslanja na objavljeno poglavlje, Nenad Miscevic, Populism and Nationalsim, in Violeta Besirevic (ed), New Politics of Decisionism, Eleven International Publishing, the Hague, 2019, pp. 61-90. Zahvaljujem se urednici zbornika New Politics of Decisionism, Violeti Beširević, urednici Političkih perspektiva Ani Matan i kolegi Zvonimiru Šikiću na korisnim komentarima. 
POLITIČKE PERSPEKTIVE

ČLANCI I STUDIJE

\section{UvOD}

Desni je populizam u usponu, po svijetu, u našoj bližoj okolini, a čini se i u Hrvatskoj. Tome svjedoče rasprave o predstavniku Srpske demokratske stranke Miloradu Pupovcu, razgovori u televizijskoj emisiji Bujica, kolumne na portalu Narod.hr i komentari čitatelja na vijesti o Bleiburgu i sličnim temama. Izbjeglička je kriza ${ }^{2}$ pružila gorivo za takav desničarski antiimigrantski populizam i pomogla oživjeti stare, pomalo zamrle teme poput Bleiburga ${ }^{3}$. A desna reakcija na izbjegličku krizu prilično je dramatična. Evo kratke ilustracije s jednog hrvatskog portala:

Sudeći po faznom razvoju događaja i iznijetim ciljevima Marakeške deklaracije, europski fokus djelovanja očito je preusmjeren sa sprječavanja ilegalne u planiranje i poticanje legalne migracije iz Afrike u Europu. U stvari, radi se o skrivenom planu legalnog preseljenja velikog broja ljudi iz Afrike u Europu. Teret tog procesa bi naravno morale podnijeti države „potpisnice” deklaracije.

Mađarska vlada je za sada jedina koja je o toj temi pitala vlastiti narod (od kojeg je izabrana); što o tome misli i podržava li takav sporazum, jer, ipak, o njihovoj se zemlji i budućnosti radi. Temeljeno na mandatu koji je dobila od svojih birača, mađarska vlada smatra da je njihova dužnost na prvo mjesto staviti interese vlastitog naroda i države koji se ne podudaraju s migrantskom politikom EU-a. Za razliku od naših susjeda koji su odbili podržati Marakešku deklaraciju u svibnju ove godine, ostale europske države (zajedno s Hrvatskom) misle da je potpuno irelevantno što njihovi građani misle o imigracijama Afrikanaca u njihove zemlje. (Narod.hr 2018)

Dok ovo pišem, izborne ankete predviđaju da će trećina mjesta na izborima za Europski parlament 2019. pripasti strankama koje izlaze iz tradicionalnog okvira demokršćanskih /socijaldemokratskih opcija; za očekivati je da će značajan njihov dio činiti euroskeptične desne populističke stranke. U našoj užoj okolini utjecaj desnog populizma raste: u Mađarskoj, Orbanova je stranka na vlasti, moćna i popularna, u Srbiji masovne proteste vode Dveri srpske, izrazito desna populistička stranka ${ }^{4}$, u Bosni i Hercegovini populizma ne manjka, a Austrija i Italija prepustile su nešto

2 Podaci govore da je u zadnje 4 godine samo u južnu Italiju pristiglo 6oo.ooo migranata. Procjenjuje se da je 2016. godine 362.0oo izbjeglica i migranata riskiralo svoj život u prijelazu Sredozemnog mora, s tim da je 181.400 pristiglo u Italiju, a 173.450 u Grčku. U prvoj polovici 2017. više od 105.ooo izbjeglica i migranata ušlo je u Europu. Govorimo ovdje o migrantskoj krizi od polovice zadnje dekade, ne razlikujući posebno njene razne faze jer nas prvenstveno zanimaju reakcije na nju.

3 Tako se čini ako se pogledaju razgovori u televizijskoj emisiji „Bujica” na Z1 televiziji, osobito one o migrantskoj krizi od 5.11.2018; ako se čitaju kolumne na portalu „Narod.hr” i komentari čitatelja na vijesti o Bleiburgu i sličnim temama

4 Naš naslov aludira na njihovo obećanje „Vratit ćemo narodu državu”, iz njihovog službenog programa dostupnog na http://www.dverisrpske.com/ 
vlasti populističkim strankama, s po jednom izrazito desnom u vladi svake od njih. U Sloveniji se Janšina stranka SDS pomakla jače udesno, u smjeru populizma, s časopisom „Demokracija”, koji je, čini se, tijesno povezan s Orbanom i njegovim istomišljenicima. ${ }^{5}$

No, populizam posvuda nailazi i na otpor. Protiv njega su značajni politički faktori na vlasti, ali i civilno društvo, koje organizira pomoć izbjeglicama. U Hrvatskoj se vrh HDZ-a uspijeva oduprijeti svojoj unutarnjoj populističkoj desnici koja ga oštro pritišće (iako manjih desnih strančica na sceni ne nedostaje.)

Kako razumjeti i opisati te suprotnosti? Kako izgleda okvir političke teorije unutar kojeg bismo mogli razumjeti oboje, i populističku, i otpor na razini službene politike, civilnog društva i osobnog angažmana? Koji su pravi pojmovi za tu svrhu? Jesu li to „nacionalizam”, „antinacionalizam” i „kozmopolitizam”? ${ }^{6}$ Ne sasvim: antiimigrantski, desničarski populizam izdanak je nacionalizma, ali se razlikuje od klasičnog nacionalizma na kakvog smo navikli kod kuće. Isto tako, on traži nove oblike kozmopolitizma, gostoljubivog prema „dođošima”. Je li zato klasična suprotnost kozmopolitizma i nacionalizma mrtva? Nije. O tome govori naša priča.

Evo kratkog pregleda po odjeljcima. Ostatak ovog, uvodnog odjeljka posvećen je definiranju populizma; ujedno objašnjavamo zašto smo se odlučili za desni populizam kao našu temu. Drugi se odjeljak bavi odnosom takvog populizma i srodnih mu stajališta, posebno užeg srodnika, nacionalizma i šireg srodnika, komunitarizma (vjerskog, kulturnog). Treći se odjeljak okreće našoj zemlji: zašto Hrvatska nema jake prepoznatljive populističke stranke, kakve imaju sve njezine susjede? I na kraju, kratki se zaključak bavi načinom kako populistička problematika mijenja opći politički okvir i donosi nove zadaće političkom teoretiziranju.

Počinjemo, dakle, od početka: što je populizam? Berto Šalaj u svom pionirskom radu (2002) nudi dobru karakterizaciju:

Središnja je ideja populizma da je društvo podijeljeno u dvije homogene i antagonističke skupine: pošteni narod i korumpiranu elitu. Tako Meny i Surel (2002) naglašavaju da populizam prožima ideja dobroga, poštenog i jednostavnog naroda kojega su prevarile i izmanipulirale korumpirane, nekompetentne i međusobno umrežene elite. Populisti tvrde da društvo i politiku treba korjenito promijeniti kako bi se ukinula dominacija elita te obnovile zamisao i praksa politike kao izraza volje naroda. Svi analitičari populizma navode da populisti na narod gledaju kao na jedinstveno i homogeno tijelo. Drugim riječima, zanemaruju se klase, posebni poli- 
tički interesi i individualne potrebe. Demokracija je vladavina suverenoga homogenog naroda, a ne političara. (Šalaj 2012, 4)

Nije čudo da populizam prate demagogija i podilaženje „masama”. No, pogledajmo pobliže glavne odrednice.

U svojoj knjizi Populizam (Populism), iz 1981, Margaret Canovan govori o sedam različitih vidova populizma koje dijeli na dvije kategorije: agrarni populizam i politički populizam. U agrarni populizam Canovan ubraja seljački radikalizam (primjerice, People's Party u SAD), seljačke pokrete (poput Zelenog ustanka u Istočnoj Europi), te intelektualni agrarni socijalizam (primjer su Narodniki u Rusiji), a u politički populizam ubraja populističke diktature (poput one Peronove u Argentini), populističku demokraciju (zagovor referenduma i „participacije”), reakcionarni populizam (primjer je George Wallace i njegovi sljedbenici u SAD), te populizam političara (izgradnja neideoloških širokih koalicija koje se pozivaju na „narod”) (Canovan 1981, passim)

Mi ćemo se ipak osloniti na suvremenije definicije. Mnogi autori, poput Jan-Werner Müllera i Casa Muddea, ističu da je oblik svih populizama sličan i opisuju ga kao 'tanku' ideologiju (Müller 2016). Mudde objašnjava:

Populizam se razumije kao 'tanka' ideologija koja smatra da je društvo zapravo podijeljeno na dvije homogene i antagonističke skupine, 'pošteni' narod i 'korumpirana' elita, i koja zagovara politiku koja bi bila izraz volonté generalé (opće volje) Naroda. (Mudde 2007, 23)

Tako definiran, populizam ima dvije suprotnosti: elitizam i pluralizam (Mudde 2004, 543). Postoji, najprije, suprotnost elite i naroda ('underdog'). Moguće je, nadalje, razlikovati dva opisa 'naroda': u smislu društvenog statusa (klasa, razina dohotka, itd.) ili pak u smislu etničke i/ili kulturne pripadnosti. $^{7}$

Elita

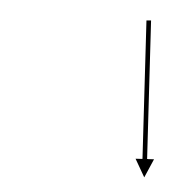

Društveni status (klasa) $\leftarrow$ Narod $\rightarrow$ etnički, kulturni opis

7 De Cleen locira 'artikulaciju' ova dva opisa specificirajući dimenziju populizma zasebnu od dimenzije elita/'underdog', a koja se tiče kontrasta između pripadnosti ili nepripadnosti grupi. B. De Cleen (2017). 
Prema drugoj, horizontalnoj dimenziji razlikuje se dominantno lijevi od dominantno desnog populizma, te se nalazi mjesto i za centrističku populističku opciju.

Elita

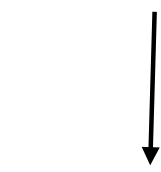

Društveni status (klasa) $\leftarrow$ Narod $\rightarrow$ etnički, kulturni opis

Lijevo Centar Desno

Lijeve stranke (izvorna SYRIZA, Podemos i latinoameričke lijeve stranke) ističu socijalnu dimenziju sukoba: siromašni protiv bogatih, niže i najniže klase protiv viših klasa i sl. Zbog toga što desne stranke imaju u vidu etnička i kulturno lingvistička obilježja 'demosa', tema ovog članka, populistički nacionalizam, svakako se nalazi na desnoj strani spektra. Centrističke stranke, poput Živog zida u Hrvatskoj, posuđuju s obje strane spektra, pa imaju, s jedne strane, ljevičarsku poziciju prema siromašnima, a s druge, izolacionističku i suverenističku prema EU i Sloveniji. Tako je čelnik Živog zida, povodom hrvatsko-slovenskog spora oko Piranskog zaljeva, izjavio da Hrvatska treba poslati ratni brod u Piranski zaljev (Novi list.hr 2018).

Mudde $(2017,27)$ ističe da je 'populizam' bitno sporni pojam (engl. essentially contested concepts), no njegovo metodološko upozorenje ne odjekuje dovoljno glasno u postojećoj literaturi. U „ideacijskom” pristupu, kako ga Mudde naziva, ono što nas zanima su odnosi među pojmovima (ili pak stvarni odnosi koji korespondiraju s odnosima među pojmovima). Primjerice, je li nacionalizam vrst populizma (ima li prošireno značenje 'populizma' sadržajno stjecište s konceptom 'nacionalizam'), i slično. Moguće je, međutim, da je odnos između populizma i njegovih pojmovnih srodnika povjesan, činjeničan i da zahtijeva objašnjenje koje je bliže kauzalnoj povijesnoj ili sociološkoj priči. ${ }^{8}$ Hrvatski desni populizam, uvijek „za dom spreman”, održava vezu čuvstvene solidarnosti s barem nekim elementima ustaškog pokreta: antisemitizam više ne igra nikakvu, ali mržnja prema Srbima igra središnju ulogu. Ako uzmemo različit primjer, mogu nas zanimati povijesno nacionalistički korijeni austrijskog populizma, pa ćemo se okrenuti povijesti Slobodarske stranke 
(Freiheitlliche Partei) i njenim uzročno-povijesnim vezama s austrijskim nacističkim snagama (uključujući i SS), te njihovom ideologijom pod nacističkom okupacijom, itd (Albertazzi and Mc Donnel 2016). Moramo, dakle, razlikovati pojmovne i kauzalne veze između nacionalizma i populizma. U nastavku članka razmotrit ćemo i jedne i druge.

Ovdje nam je bitno da je pojam „populizma” vrlo tanašan. Za Muddea je populizam antielitistička i na riječima pronarodna ideologija.

Definicija populizma kao ,tanašne” ideologije je korisno za razumijevanje navodne promjenjivosti pojma o kojemu je riječ. Ideologija je skup normativnih ideja o prirodi čovjeka i društva, o organizaciji i svrhama društva. Jednostavno rečeno, ona je slika onoga kakav svijet jest i kakav treba biti. Za razliku od „gustih” ili „potpunih” ideologija (primjerice fašizma, liberalizma, socijalizma), „tanašne” ideologije poput populizma imaju ograničenu morfologiju, koja se nužno povezuje - a ponekad i asimilira - s drugim ideologijama. Zapravo, populizam se skoro uvijek nadovezuje na druge političke projekte koji su najširoj javnosti privlačni. (Mudde and Rovira Kaltwasser 2017)

Hrvatski se stručnjaci slažu. U razgovoru o populizmu, Nenad Zakošek naglašava da se u politologiji uvriježilo govoriti o populizmu kao slaboj ideologiji, a Šalaj se na njega nadovezuje:

Druga grupa otišla je korak dalje i kažu da se populizam može promatrati kao svojevrsna politička ideologija. Dodaju, međutim, da to nije „prava” politička ideologija poput socijaldemokracije, demokršćanstva ili konzervativizma, nego ističu da je to slabo utemeljena ideologija na način da joj u jezgri nisu neke specifične vrijednosti, nego se prepoznaje po određenim strukturnim obilježjima koja je moguće kombinirati s različitim vrijednostima. Oni koji kažu da je populizam ideologija navode da on ima dva osnovna obilježja, prvo je učestalo pozitivno referiranje na narod, a drugo je snažno izraženi antielitizam. Čak se smatra da je upravo antielitizam temeljno obilježje populizma kao ideologije. Populizam, shvaćen kao ideologija, zapravo ima dva glavna suparnika - elitizam i pluralizam. (Jutarnji.hr 2015)

Problemi takvog „tankog” populizma načelni su: smije li se podilaziti „narodu”? Je li dopuštena politička laž dio prava na slobodu govora? No, ima i praktičnih: kad dođu na vlast, tzv. „populisti”, desni ili lijevi (Orban, Trump, Chavez), obično iznevjeravaju svoju retoriku, formiraju vlastitu elitu i uvode elemente diktature, protiv pluralizma (Müller 2017).

Mi ćemo ovdje krenuti od prirodne pretpostavke: tanašna ideologija nije ozbiljna politička vrsta (kao što "morska životinja” nije ozbiljna biološka vrsta). Ona nema dovoljno stabilnih karakteristika, koje bi odredile njezino ponašanje. Predlažemo da naš predmet ovdje bude specifična podvrsta, desni populizam. Taj je dovoljno određen i dovoljno bogat da nastupi kao prava politička vrsta. Naša tema je, dakle, desni populizam. 
I još nešto: u načelu može postojati loš, srednji i dobar populizam, lijevi ili desni. Mi ćemo se koncentrirati na loše varijante, koje dominiraju političkom scenom.

\section{POPULIZAM I NACIONALIZAM}

\section{(A) NEKOLIKo TEMELJNIH POJMOVA}

Pierre-André Taguieff u svojoj knjizi o populizmu koja ima vrlo rječit naslov, Osveta nacionalizma: Neopopulisti i ksenofobi u napadu na Europu (Taguieff 2017), govori o populizmu kao vrsti nacionalizma. On je smislio koristan pojam 'nacional-populizam' koji ćemo ovdje koristiti. Međutim, prilično je jasno da je nacionalizam tek jedan od mnogih političkih 'izama' koji privlače desne populiste. Migrantska kriza je pokazala mogućnosti populističke samoidentifikacije s lingvističko-kulturnim i vjerskim zajednicama (mi 'Kršćani') koja ide puno dalje od nacionalizma.

Započet ću raspravu praveći razlikovanje među političkim idejama ili ideologijama u širem polju nacionalnih ili nacionalno-sličnih privrženosti.

Najprije, nekoliko riječi o naciji. Obilježja koja grupa treba imati kako bi bila nacija su srodstvo (ili percepcija srodstva), teritorijalni kontinuitet, zajednička kultura, posebno, jezik, zajedničku povijesnu memoriju i osjećaj zajedničke sudbine (Gat and Yacobson 2013). Naciju razumijemo kao političku/državnu zajednicu koja na središnje mjesto stavlja zajedničke osjećaje, identitet, solidarnost i udruženost naroda, definiranog kulturom i osjećajem srodstva, u jednoj državi.

Nadalje, najpoznatije modernističko objašnjenje nacionalizma je ono Ernsta Gellnera (1983). Nacionalizam zahtijeva preklapanje kulturne zajednice i države. ${ }^{9}$ Klasični nacionalizam je politički program po kojem je stvaranje i održavanje potpuno suverene države koja pripada etnonacionalnoj skupini ('narodu' ili 'naciji') najvažnija dužnost svakog pripadnika te skupine. Polazeći od pretpostavke da je primjerena (ili 'prirodna') kulturna jedinica etnička nacija, klasični nacionalizam smatra da je primarna dužnost svakog pripadnika nacije da se u kulturnim pitanjima drži svoje etnonacionalne kulture. U SAD se ovakvi stavovi zovu 'nativizam'. Klasični nacionalisti su obično vrlo osjetljivi na kulturu koju štite i promoviraju i na stavove koji ljudi imaju o njihovoj nacionalnoj državi. Ovaj zaštitnički stav nosi sa sobom potencijalne opasnosti: mnogi elementi

9 Za Gellnera, nacija i industrijsko društvo usko su povezani. Industrijsko društvo zahtijeva homogenost, pa je stoga vrsta kulturalne homogenosti koju zahtijeva nacionalizam produkt industrijskog društva i morali bismo ju prihvatiti kao neizbježnu. Nacija je zato proizvod doba nacionalizma, te se može definirati jedino u tom kontekstu. 
kulture koji nisu prepoznati kao nacionalni mogu biti, a ponekad i jesu, žrtvovani tom nacionalnom entuzijazmu. Klasični nacionalizam, u svakodnevnom životu, postavlja svakojake zahtjeve pred pojedince, od kupnje skupljih domaćih proizvoda umjesto jeftinijih iz uvoza do prokreacije što većeg broja budućih pripadnika nacije.

Pored klasičnog nacionalizma (i njegovih radikalnijih ekstremističkih rođaka), postoje i razne umjerene ideje koje se također ubrajaju u nacionalističke. U stvari, filozofska rasprava se pomaknula u pravcu ovih umjerenih do ultraumjerenih ideja, i većina filozofa, koji sebe opisuje kao nacionaliste, predlaže vrlo umjerene nacionalističke programe. U nastavku ćemo ih ukratko opisati.

Nacionalizam $u$ širem smislu je svaki sklop stavova, tvrdnji i uputa za djelovanje koji pripisuje fundamentalnu političku, moralnu i kulturnu vrijednost naciji i nacionalnosti, te dužnostima koje proizlaze iz tih vrijednosti (bilo za pripadnike nacije ili pak za treće strane, individualno ili kolektivno). Postoje dvije verzije (i neke podverzije) ovog šire shvaćenog nacionalizma. Prva je umjereni državni nacionalizam, gdje je nacionalistički program ublažen minimalnim skupom prihvaćenih ljudskih prava, posebno prava manjina (primjerice, država Austrija pripada ponajprije Austrijancima, no njeni etnički različiti pripadnici - Slovenci, Mađari i ostali, imaju manjinska prava), te zahtjevima parlamentarnih sustava. Druga verzija je još manje tradicionalno nacionalistička; radi se o liberalnom nacionalizmu koji je prijateljski raspoložen prema manjinama, a ne samo tolerantan prema njima, koji može prerasti u zagovor multietničke, multinacionalne države.

U ostatku ću ovog odjeljka raspravljati o patriotizmu, kategoriji bliskoj nacionalizmu, koja se često sagledava zasebno. Potom ću se osvrnuti na vrste nacionalizma, koje su centralna tema. Slijedi diskusija o široj populističkoj alternativi - komunitarnom nenacionalnom pripadanju: primjerice bivanju kršćaninom (u vrlo širokom smislu) nasuprot bivanju muslimanom. To je ključna populistička alternativa etnonacionalnom identitetu koja pokazuje da populizam nije istovjetan nacionalizmu. Završit ću odjeljak s nekoliko riječi o kozmopolitizmu, alternativi tradicionalno suprotstavljenoj nacionalizmu i njegovom eventualnom odnosu s populizmom.

Započnimo s patriotizmom. Termin 'patriotizam' koristi se za mnoga značenja. Nekada se razumije kao usmjerenost prema vlastitoj 'partiji': patriotizam je privrženost vlastitoj državi nasuprot privrženosti vlastitom narodu i njegovim tradicijama (nacionalizam). Nekada se smatra mnogo manje agresivnim od nacionalizma. Pred gotovo tričetvrt stoljeća George Orwell je napisao da je „patriotizam po svojoj prirodi obramben, kako vojno tako i kulturološki. Nacionalizam je, s druge strane, nemoguće odvojiti od želje za moći." (Orwell 200o, 469) Zajedno, dva se para obilježja 
(teritorij nasuprot etničkoj zajednici i umjerenost nasuprot ekstremizmu) često smatraju određujućim obilježjima patriotizma. Naravno, termin korišten u stvarnom političkom diskursu mnogo je neprecizniji od onoga standardnoga u teorijskim ogledima. U SAD se 'patriotizam' često koristi za shvaćanje/a koje bi teorijska literatura opisala kao 'nacionalističko'. Jedan je od problema što ljubav prema državi nije zapravo samo ljubav prema komadu zemlje; uobičajeno, ona uključuje i privrženost zajednici njenih žitelja, a to uvodi 'naciju' u koncepciju patriotizma.

Moguće je razlikovati patriotizam niskog od onoga visokog profila, koji je vrlo srodan nacionalizmu, ili Nathansonovom terminologijom, umjereni i neumjereni, tj. ekstremni patriotizam (Nathanson 1993, 30). Patriotizam visokog profila može biti agresivan prema drugima, dok je onaj niskog profila više unutarnje orijentiran. Patriotizam visokog profila nalaže svome poborniku vjeru u neku vrst superiornosti vlastite patrie, od one bezopasne i konvencijama regulirane u sportu, preko inzistiranja na navodnim jedinstvenim vrlinama vlastite zemlje, sve do podsmijeha, prezira i omalovažavanja drugih. Patriotizam niskog profila kompatibilan je s visokim uvažavanjem drugih te može postojati paralelno s umjerenim kozmopolitskim stavovima (Ibid.).

Patriotizam niskog profila nije baš privlačan desničarskom populistu. Mnogo je zanimljiviji ljevici. Ilustrativan je primjer intelektualaca koji su se borili u Internacionalnim brigadama u Španjolskom građanskom ratu, koji su bili internacionalisti, no ujedno su podržavali i patriotizam svojih španjolskih suboraca. Moguće je govoriti o 'lijevom patriotizmu' ili, slijedeći Orwellov termin, 'revolucionarnom patriotizmu'.

Orwellu se u njegovim revolucionarnim patriotskim osjećajima pridružuju i drugi lijevi intelektualci, kao što je australski pjesnik i borac Jack Lindsay, koji je napisao Rekvijem za pale Engleze u Internacionalnoj brigadi (1938). Otvoreno je pitanje možemo li ove intelektualce nazvati 'lijevim populistima'. No, kada bi nam trebali primjeri oni bi nam možda mogli poslužiti u tu svrhu.

Rado bih kratko spomenuo tipičniju kombinaciju: desni populizam i patriotizam visokoga profila koji si dobro pristaju. Roger Scruton, najpoznatiji britanski branitelj takvog patriotizma, približava ga nacionalizmu, te piše da patriotizam/nacionalizam naglašavaju političku odanost. Usredotočenost na nacionalno izvire iz same prirode moderne države. Pravo i zakonitost zahtijevaju nadležnost, no sigurnost, kontinuitet i stabilnost, koji su pretpostavke vladavine prava, nedostižne su sve dok teritorij nije osiguran. Nacionalna je odanost istovjetna patriotizmu: odanost vlastitoj državi, prirodna ljubav prema državi, sugrađanima i kulturi koja ih objedinjuje (Scruton 2006, 4). 
Doista, patrioti su privrženi ljudima i teritoriju koji je njihov po pravici; a patriotizam uključuje pokušaj da se tu pravicu pretvori u nepristrasno vladanje i vladavinu prava. Teritorijalna je odanost, možda se može ustvrditi, u korijenu svega.

Kada bismo apstrahirali Scrutonovu simpatiju prema vladavini prava, općenito bi smisao njegovog patriotizma odgovarao mogućem populističkom stavu. Primjerice, prema Centru za istraživanje Brexita, relevantna istraživačka pitanja su, između ostalih, sljedeća dva:

„Što je 'novo' u trenutnom populizmu u Britaniji zahvaćenoj politikom štednje? Možemo li spoj animoziteta prema državi blagostanja i ekonomskog protekcionizma nazvati populističkim?

Kako patriotizam i populizam oblikuju novi odnos Britanije s EU?" (Centre for Brexit Studies, 2019)

Pitanja sugeriraju da je Brexit povezan s populističkim patriotizmom, očito s njegovom varijantom visokog profila. Problem je u tome što je razlika između patriotizma visokog profila i klasičnog nacionalizma minimalna. Glasoviti autori, poput Scrutona, zajedno ih grupiraju u jedinstveno stajalište s obzirom na to da populistička politika nije dovoljno suptilna da bi održala njihovo razlikovanje. Sugerirao bih da se u populističkom kontekstu (ako ne i drugdje) patriotizam visokog profila urušava u klasični nacionalizam.

Sociolozi i politolozi danas ističu da su neke zemlje, Hrvatska, kao i njezina bliža okolina, Mađarska, Slovenija, Srbija, i vrlo dramatično $\mathrm{BiH}$, obilježene slijedećom glavnom unutarnjom suprotnošću: umjesto klasnog - ekonomskog rascjepa, u tim zemljama politička opredjeljenja definira rascjep temeljen na suprotnosti nacionalnog/anacionalnog (federalnog ili sličnog), uronjen u kontekst povijesnih savezništava i neprijateljstava. Za Hrvatsku navodimo nekoliko citata. Andrija Henjak piše:

Dosadašnje analize izbornoga ponašanja u Hrvatskoj pokazale su izražene podjele među biračima oko simboličnih i identitetskih pitanja, utemeljenih na različitom odnosu prema religiji, tradiciji i povijesti koje su oblikovale obrasce izbornoga ponašanja nakon neovisnosti i u konačnici dovele do konsolidacije bipolarnog obrasca političkoga natjecanja nakon 2000. godine (Henjak 2018, 383).

Goran Čular precizira ovaj kontrast na slijedeći način:

Usprkos sve učestalijim intelektualnim kritikama svrsishodnosti lijevo-desne simbolike u politici, naša istraživanja pokazuju da s vremenom biračko pozicioniranje na lijevo-desnom kontinuumu postaje sve konzistentnije s njihovim stranačkim preferencijama. Pri tome valja naglasiti da u vrijednosno-ideološkom smislu lijevo-desna shema u Hrvatskoj sadržajno najviše odgovara kulturalnoj dimenziji gdje je, na jednoj strani, liberalizam, kozmopolitizam i multikulturalizam, a na drugoj, konzervativizam i etnonacionalizam. U smislu temeljnih socijalnih identiteta, u koje 
NENAD MIŠČEVIĆ

„VRATIT ĆEMO NARODU DRŽAVU” - DESNI POPULIZAM,

NACIONALIZAM I NOVI IZAZOVI

je lijevo-desna shema bila uronjena tijekom cijelog razdoblja, naša su istraživanja pokazala da su jaki religijski identitet i institucionalna vezanost za Crkvu kontinuirano povezani s desnicom, a nedostatak takvog identiteta s ljevicom. (Čular 2004, 139)

Vrijedno je spomenuti neetnički regionalizam, poput onoga stranke Lega Nord u Italiji (donedavno, kada je promijenila ime i politiku). Takav regionalizam zahtijeva državnost za pojedinu regiju, no ne zbog nacionalističko-etničkih kriterija. Primjerice, u Italiji je Padania trebala imati pravo postati državom s obzirom na to da je ekonomski i politički napredna u odnosu na ostatak Italije. Postupci populista u ovom kontekstu sliče nacionalnom populizmu i primjeru Lega Nord, koja je nedavno odustala od regionalizma u korist tradicionalnijeg talijanskog nacionalizma. Ovaj primjer dobro ilustrira afinitet između nacionalizma i neetničkog regionalizma. Razlika je, pak, u neetničkom karakteru osobitosti koje bi regiju trebale učiniti podobnom za status države.

\section{(B) KLASIČNI SNAŽNI ETNONACIONALIZAM}

Populizam i klasični snažni etnički nacionalizam vrlo su usko povezani. To je navelo neke teoretičare da nacionalistički populizam prezentiraju kao sam populizam. Taguieff je najpoznatiji autor koji tvrdi da je patriotizam samo varijanta nacionalizma. Njegov termin 'nacionalpopulizam' ('national-populisme') nalazimo već u njegovom članku iz 1984. (Taguieff 1984) o 'Retorici nacionalpopulizma', koji se bavi stilom francuskog Nacionalnog fronta (koji je tada vodio Jean-Marie Le Pen).

Termin je preživio sve do naših dana (Pantazopoulos 2016) i koristit ćemo ga ovdje. Čini se da točno zahvaća sintezu populizma i snažnog etničkog nacionalizma ili nativizma. Od populizma uzima opću shemu antielitizma: vođa se obraća direktno narodu te navodno slijedi njegove interese. Od nacionalizma uzima karakterizaciju naroda: to je etnička zajednica, u većini slučajeva etnička zajednica koja „ima državu”, ili etnonacija. U svom radu Mudde dokumentira ideju da jedino desničarski populisti tvrde da predstavljaju pravi narod koji tvori pravu naciju čija se čistoća narušava novim došljacima. Kako bi naglasio ove odlike, koristi termin 'nativizam': „nativizam je ovdje definiran kao ideologija, koja smatra da bi države trebale biti napučene isključivo članovima izvornog stanovništva, 'nacijom', te da su neizvorni elementi (ljudi i ideje) fundamentalno opasni za homogenu naciju-državu”. (Mudde 2007, 19; Mudde 2004, 542-563)

Grotesknu ilustraciju snažnog nacionalnog populizma nudi nam slovensko društvo „Hervardi”. Njegov osnivač Andrej Šiško ovako opisuje odlike starih Slovenaca, povezane s podrijetlom riječi:

Korijen riječi „her” označava hrabro ratovanje. Značenje riječi „heraj” se danas sačuvalo u riječi „haraj”, koja znači „skinuti dlake” ili „oderati”. Poznato je da 


\section{8 \\ POLITIČKE PERSPEKTIVE \\ ČLANCI I STUDIJE}

Bugari i danas pamte da su slovenski vojnici bili izvanredni majstori koji su znali oderati živog čovjeka u nekoliko sekundi. (Hervardi.com)

Konačno, kratko ću se osvrnuti na obrnuti ekstrem, autore koji minimiziraju ili negiraju relevantnost nacionalizma za populizam. Benjamin Arditi (2007) takav je primjer. ${ }^{10}$ Tvrdi da su se „[...] stvari poprilično radikalno promijenile zadnjih godina a da nisu razriješile polemiku oko značenja termina populizam. Populizam danas, čini se, ima vrlo malo toga zajedničkog sa svojim klasičnim referentom [...]” Potom prelazi na pitanje o referentu i tvrdi da su kao mete populističkog entuzijazma

[...] nacionalizam i ekonomski protekcionizam praktički ... nestali, a narodna mobilizacija većinom je minimizirana; umjesto toga, preostalo nam je ono što neki opisuju kao brak iz interesa između neoliberalne ekonomije i neopopulističke politike [...]. (Arditi 2006, 56) $)^{11}$

Kako bi podupro ove tvrdnje osvrće se jedino na svoju Latinsku Ameriku; ne spominju se niti analiziraju primjeri europskog ili populizma iz SAD. Nacionalizam je praktički nestao, tvrdi. U vrijeme pisanja knjige u Italiji smo imali Berlusconija, u Francuskoj Nacionalnu frontu, u Velikoj Britaniji UKIP (utemeljen devedesetih), a ni u postkomunističkoj Srednjoj Europi nije manjkalo nacionalističkih stranaka. Stoga ne čudi da mu je preostao termin „neprecizan” objekt, posuđen od Deleuzea i Guattarija (Arditi 2007, 57). No, njegova karakterizacija populizma kao nepreciznog objekta samo elegantno imenuje konfuziju koja mu je u temelju.

Zaključno, klasični je snažni etnonacionalizam vrlo relevantan za povijesnu genezu i konceptualno razumijevanje populizma; njegova je kombinacija s populizmom, nacionalni populizam, jedna od središnjih varijanta populizma, koja je prominentna na nekoliko kontinenata.

\section{(c) UMJERENI DRŽAVNI NACIONALIZAM}

Sada se okrećem opciji bliskoj klasičnom nacionalizmu, uz razliku da se nalazi na desnom centru, a ne na 'čistoj' desnici. U slučaju takvog umjerenog državnog nacionalizma, nacionalistički je program omekšan vladavinom prava (koja uključuje prihvaćanje minimalnog skupa ljudskih prava te, konkretno, manjinskih prava), a ujedno i zahtjevima parlamentarnih sistema.

U potrazi za primjerima, referirat ću se na korisnu knjigu Iavora Rangelova (2013) o recentnoj povijesti promjena na Balkanu. On s pravom opaža da

[P]ravo ima osobitu i prilično ambivalentnu ulogu u konstruktu etničkog državljanstva, [...]: služi kao instrument formalizacije i kodifikacije članstva 
povezanog s pojedinim projektima države-nacije i, $u$ isto vrijeme, omogućava prostor za potencijalno pobijanje i transformaciju državljanstva prema alternativnim logikama i normativitetima. (Rangelov 2013, 20)

Klasično nacionalistički akter ne mora uzeti u obzir ove alternative. On ili ona nastavljaju braniti uske interese etniciteta. 'Slovenija Slovencima' najdraži je slogan slovenskih nacionalnih populista, koju katkada prati dodatak 'Stranci van!' Prosječan slovenski političar ne može si dopustiti korištenje takvog slogana zbog jakog sistema zaštite ljudskih prava koji je izgradila slovenska država, a koji je inicirala ne samo matica slovenskih političara već i lokalni NGO-ovi, a snažno ga podržava i EU.

U takvom aranžmanu reguliranom pravilima, vladajuća nacionalistička elita nije mogla utišati glas nenacionalističke opozicije u parlamentu i u lokalnim predstavničkim tijelima. U Sloveniji je to bio slučaj s desničarskom Janšinom vladom (koji je dva puta bio premijer Slovenije, drugi put između 2012. i 2013), čije su nacionalističke ambicije na svakom koraku bile osujećene vrlo moćnom i aktivnom opozicijom. U kontekstu sadašnjeg trenutka, ovo je važno jer bi aranžman reguliran pravilima mogao minimizirati ili blokirati mogućnost populističkog rješenja. Struja nacionalnog populizma treba slobodan prostor, no ne može ga naći u situaciji gdje je vladajuća garnitura očito patriotska. Stoga je i iznad optužbe da se sastoji od izdajnika, a aktivnosti su joj striktno ograničene vladavinom prava i preciznije ljudskim pravima, na način koji ne ostavlja mogućnost za populističku 'spontanost' lidera. Čini se da SAD prolazi kroz simetričan proces, gdje se Trumpov populizam neprestano sudara s Ustavom i pravnim sustavom.

Rangelov posvećuje cijelo poglavlje primjeru važnome za Balkan, a možda i za druga područja, koji se odnosi na miješanje međunarodnog sistema vladavine prava u kontekst lokalnih ratnih zločina:

Ključan izazov tranzicijske pravde u Hrvatskoj od početka novoga stoljeća bila je potreba suočavanja s dva nasljeđa zlostavljanja: jednog koji uključuje zlodjela protiv srpskih civila i etničkog čišćenja tijekom Domovinskog rata; drugog koji se tiče provođenja suđenja za ratne zločine nakon njegovog svršetka. Hrvatsko se pravo, kao i politička klasa i javnost, nisu adekvatno suočili s ovim nasljeđima i pomirila se s prošlošću. Ipak, hrvatsko je iskustvo s pravosudnim procesima u zadnjem desetljeću korisno za osvjetljavanje potencijala deliberativne tranzicijske pravde $u$ ispitivanju 'tamne strane' nacionalizma, kao i u otkrivanju nekih od njegovih ograničenja. (Rangelov 2013, 162) $)^{12}$

Proširujući spektar primjera, Netanyahuov Izrael mogao bi biti tipičan slučaj države s umjerenim državnim nacionalizmom kao vodećom ideologijom. Pretvorio bi se u neumjerenu, klasično nacionalističku varijantu da 
POLITIČKE PERSPEKTIVE

ČLANCI I STUDIJE

nema konstantne, glasne kritike i aktivne borbe lokalne palestinske opozicije, kritike lokalne izraelske opozicije, šire arapske osude, te međunarodnog nadgledanja i kritike. Treba spomenuti nedavni dramatični primjer Ahed Tamimi; populističko nacionalistička država mogla bi si dozvoliti uhićenje i zatvaranje djevojčice tinejdžerske dobi koja pripada manjinskoj skupini. Sad kad je postala nacionalni palestinski simbol otpora, uhićenje i zatvor čine se kao nerazumne reakcije, a vladavina prava sprječava mogućeg populista da negativno ili nasilno reagira. Stoga, nužnost poštovanja zakona, čak i uz ponešto varanja, zaobilaženja procedura, itd., onemogućuju Netanyahuovu vlast da postane čisti primjer nacionalnog populizma.

To ne čini umjereni nacionalizam desnog centra idealnim, pa ni bliskim idealnom. Za moj osobni, poprilično kozmopolitski ukus, on je samo manje zlo od neumjerenog, čisto desnog nacionalizma, no može biti vrlo koristan za sprječavanje populističke opasnosti. Pokušat ću to dokumentirati u drugom odjeljku na primjeru Hrvatske.

\section{(D) KOMUNITARIZAM I 'TRANSNACIONALNI NACIONALIZAM'}

Sada prelazim na glavnu populističku alternativu (ili kvazialternativu), na nacionalni populizam. Već je spomenuto da u nekim zemljama neke populističke grupe - stranke - imaju širu privlačnost od etnonacionalne pripadnosti, a tipično religijske pripadnosti. Druge grupe objedinjavaju ovu privlačnost s etnonacionalističkom. Ti fenomeni glavni su dokaz šire privlačnosti populizma - a protiv Taguieffovog isključivog fokusiranja na nacionalni populizam i njegovu identifikaciju s populizmom.

Započet ću s nekoliko ilustracija. Marijo Popović spaja hrvatsko rodoljublje s kršćanskim identitetom u blogu „Neka stranka 'Pametno' ustupi svoje prostorije muslimanskoj zajednici za molitvene rituale”,

Poštivati treba svakoga kao ljudsko biće, ali hrvatski narod i katolička vjera su ono što treba imati prioritet u našoj domovini.

Hrvatski narod opstao je ponajprije zahvaljujući svojoj vjeri i katoličkom nauku koji nas je održao kroz stoljeća i upravo je to jedan od temelja našega društva. (Narod.hr 2019)

Slovenska „Demokracija” je tu mnogo sustavnija. Ona normalno brani kršćanski identitet protiv Arapa koje, od naslovnica nadalje, predstavlja kao silovatelje i ubojice. No, prilikom gradonačelničkih izbora u proljeće 2019, odjednom se okrenula protiv kandidata srpskog podrijetla, zaboravivši da su Srbi jednako kršćanski narod kao i Slovenci. ${ }^{13}$

13 Slično je i u Hrvatskoj s televizijskom emisijom „Bujica”. S jedne strane, u njoj se nađu antimuslimanski ispadi, a s druge antisrpski, iako su Srbi kršćani, a ne muslimani. Samo da ponudimo primjer, ovdje je vijest o izjavama koje su u studenom prošle godine uzburkale javnost: 
Njemačka je stranka AfD (Alternativa za Njemačku), inače poprilično uspješna na parlamentarnim izborima, proizvela niz postera od kojih se neki fokusiraju isključivo na kulturološke razlike, a drugi objedinjuju širu kulturološku pripadnost s nacionalnom. Uzmimo primjer s muslimanskom burkom. Prvo citira predsjednika Gaucka, prikazujući ga prekrivenog burkom; njegov je krimen bio što je izgovorio „Burka? Mogu i te kako živjeti s njom". Potom je na istom posteru slika burke sa znakom stop i tekstom: „Burka? Ne hvala!” Drugi se slično referiraju na ramazanski post. Posteri lijepo ilustriraju privlačnost isključivo širim kulturalnim pripadanjem, a ne usko nacionalnim. U ovome je kontekstu austrijski politički filozof Harald Stelzer govorio o komunitarističkim stavovima, pa čak i komunitarizmu simpliciter (Stelzer 2018).

U svojem je širem značenju komunitarizam obilježen tezom da je pripadanje zajednici, po mogućnosti onoj koja dijeli jezik, tradiciju, itd., preduvjet za nečiji bogati identitet. Ova ideja vodi prema odbacivanju snažnog individualizma i gotovo esencijalističkom pogledu na kulturološka svojstva kao određujuća za identitet svojih individualnih nositelja. U komunitarističkoj tradiciji tipično razmišljanje o pitanjima o pripadanju kreće tvrdnjom da su uvjeti nečijeg identiteta neophodni za puni ljudski subjektivitet, tada dodaje tvrdnju da je ključni pol identifikacije jezik s kulturom, prelazi na ideju da je dostupnost lingvističko-kulturološke zajednice neophodna za puni ljudski subjektivitet, te zaključuje da imamo pravo zahtijevati od drugih da poštuju naše komunitarno pripadanje. Ovako rezonira Charles Taylor. MacIntyreova je verzija više nacionalistička i zahtjevnija, dok Walzer i Sandel zvuče umjerenije, no općenito je to oblik zajednički komunitarističkoj tradiciji. Mnogi vodeći komunitaristički mislioci odbacuju tu oznaku, no za potrebe ove diskusije smatrat ću sve ove autore komunitaristima.

U svojem već spomenutom radu o komunitarizmu i populizmu Harold Stelzer kao njima zajedničke elemente navodi važnost 'individualnog identiteta uklopljenog u zajednicu', kritiku liberalnog shvaćanja demokracije, strah od kulturološkog rastvaranja i pretpostavku o homogenosti kolektiviteta. Na dubljoj razini, predlažem da se naglasak stavi na zajedničko shvaćanje dobra, koje je eksplicitno u komunitarističkoj teoriji, a implicitno u nekim populističkim retorikama, premda Stelzer ne ocrtava tu distinkciju

Podsjetimo, dok je osuđeni diler (Velimir Bujanec, op. a.) koji je ljubav prostitutke plaćao kokainom ustvrdio da u Njemačkoj „divljaci koji su došli s istoka siluju, a tamošnji mediji o tome ne izvještavaju”, njegov je gost Zoran Grgić netom nakon toga kazao kako „crnčuge i arapčuge siluju, ubijaju i teroriziraju po svijetu”. Grgić je kasnije iznio i teoriju da su „oni koji dolaze iz mediteranskog, saharskog i subsaharskog područja uglavnom zaraženi sidom i hepatitisom, a jako puno ih ima i tuberkulozu. (Net.hr. 2018)

Istodobno, Bujančevi gosti bjesne na Srbiju i Srbe, na stvarne i moguće posjete članova jednog vrha drugome, kao i na Srbe u Hrvatskoj. (Bujica 2019) 
POLITIČKE PERSPEKTIVE

ČLANCI I STUDIJE

između eksplicitnog i implicitnog. Za njega je dubinski zajednički element kritika liberalnog poimanja sebstva. Nisam siguran da su postojeći populizmi dovoljno suptilni da se oglase o ovom pitanju.

Prema tome, s obzirom na to da 'komunitarizam' obično označava teorije, pa čak i filozofske teorije, treba potcrtati 'praktični komunitarizam' kako bi se razlikovao politički aktivizam, kao onaj na posterima, od teorijskih elaboracija.

Kao što je za očekivati, posteri AfD-a ujedno su privlačni i etnonacionalnom pripadanju. Neki primjerice prikazuju mlade žene u bikinijima s komentarom „Burke? Više volimo bikinije”, ali tada nadodaju slogan: „Nijemče, budi samopouzdan”. Područje se mijenja: od nacionalnog, do šireg komunitarnog, do njihove kombinacije. Stoga ću se referirati na 'širi praktični komunitarizam', te se koncentirati na njegovu neliberalnu varijantu. U filozofiji bi to možda bilo blisko MacIntyreu, no u mnogo manje civiliziranoj formi (MacIntyre 2002). Naravno, liberalniji komunitarizam Sandelovog ili Walzerovog stila nije dokumentiran u širem praktičnom kontekstu populističke ideologije. ${ }^{14}$ Ideja krugova kulturološkog pripadanja poprilično jednakih moralnih težina, koju naglašavaju liberalni komunitarci, beskorisna je desničarskim populistima. Ne bi pomoglo ni kada biste im rekli da su Latinoamerikanci, dakle da nisu Angloamerikanci, ali da dijele kršćansku vjeru s mnogim Angloamerikancima, a katoličku vjeroispovijest s američkim Ircima, Poljacima ili Hrvatima. U datom se kontekstu odabire pojedino pripadanje Drugoga kao meta, te kontrastira s 'oprečnom' afilijacijom, kojoj pripadamo „Mi” i točka. Snažnu, desno populističku varijantu ove komunitarističke strategije karakterizira 'transnacionalni nacionalizam': transnacionalna prema objektu identifikacije, ali je blizak nacionalizmu po tipu shvaćanja od kojih se sastoji. Termin dolazi od Rive Kastoryano (2006).

Relevantno za ovu raspravu je uočiti plastičnost-podatnost praktičnog komunitarnog pripadanja. 'Nacionalizmi' se sagledavaju (s pravom) kao poprilično kruti u svojim gledištima: hrvatski nacionalist navija za Hrvate i njihovu zajednicu, itd. Zanimljivo je da su autori koji su pisali o ovoj temi, među kojima je i Stelzer, rijetko uočili ovu centralnu novinu koju je donio populizam, fleksibilnost i podatnost partikuralističke opcije. Ponovimo, populizam se može odrediti prema bilo kojem od većeg broja faktora: prema etnicitetu ili, rjeđe, državnoj nacionalnosti, ili prema bilo kojem kulturološko-lingvističkom komunitarnom pripadanju, suprotstavljenome parnjaku iz svoje vrste istoga ranga: katolici protiv pravoslavaca, kršćani protiv muslimana, mi Nijemci (tipično kršćani, no ujedno i ateisti) protiv muslimana, itd. 
Naravno, pripadnost se prikazuje selektivno. Mi Hrvati smo kršćani, ali to ne znači da trebamo slijediti Papu u njegovoj solidarnosti s izbjeglicama; sućut prema lutalicama bez doma („A tuđincu, siromahu, Još je veći mrak u mraku, Još je tvrđa zemlja tvrda!“) nije po toj zamisli dio hrvatskog razumijevanja kršćanstva; rušenje minareta jest.

Ove će mogućnosti biti na raspolaganju za ad hoc mete populističkim političarima. Ponovno se korisnim pokazuje razlikovanje između kauzalnih i konceptualnih veza. Konceptualne veze (ili veze društvenih vrsta) su ove: ciljani je populus povezan s drugim populima određenim značajkama, a suprotstavljen, obrnutim ili kvaziobrnutim značajkama. Hrvati su bliski Slovencima po istom katoličkom vjeroispovijesti te vrlo sličnim jezikom (postoje narječja, poput istarskog i nekih varijanti kajkavskog, koji su prisutni kod oba jezika). Razlikuju se od Slovenaca stoga što su neSlovenci, narod bivše Jugoslavije. ${ }^{15}$

Koje će transnacionalno razlikovanje odabrati populistički retor? Odluka ovisi o kauzalnim silama u relevantnom kontekstu. Ako situacija traži udaljavanje vlastitog naroda od svoje jugoslavenske prošlosti, Janši najdraži kontekst bit će govora o Čefurjima. Ako pak situacija zahtijeva svrstavanje uz 'Zapad', za razliku od svojeg srednjoeuropskog identiteta, racionalno će biti naglasiti 'zapadni', više 'europski' karakter slovenske nacionalnosti, te će nas Hrvate grupirati u kategoriju susjeda ili kvazisusjeda s 'primitivnog Balkana'.

Zaključit ću ovaj odjeljak naglašavajući kako uspon populizma mijenja politički okvir kojem se trebamo baviti. Uzmimo u razmatranje obrnutu, antipopulističku stranu. Nenacionalistička, tolerantna gledišta suočavaju se s novim problemima u doba populizma obilježenog migracijskom krizom. Suočeni smo s ovim novim okvirom i populističkim izazovom. Kako bismo na njega trebali reagirati? Ključni je primjer imigracije i imigranata, najdraže teme današnje populističke promidžbe. Autori spominju suverenizam kako bi opisali ovaj populistički povratak nacionalizmu s ksenofobijom. Primjerice, u svojoj recentnoj knjizi Teodor Tudoroiu ističe da, kako bismo shvatili Brexit, moramo sagledati nove faktore koji nisu bili prisutni pred nekoliko desetaka godina. On tu navodi i populizam, ali i njegove korijene u nezadovoljstvu radničke klase svojom ekonomskom situacijom i onome što percipiraju kao imigracijsku prijetnju (Tudoroiu 2018, 104).

Zatim, novi se nacionalizam spreman preoblikovati na način koji je bio nezamisliv njegovom klasičnom prethodniku. Pronalazak novih neprijatelja, dovoljno jakih da mobiliziraju vlastiti 'narod', zahtijeva zamišljanje novih solidarnosti: ako je novi neprijatelj musliman, tradicionalno će rival-

15 Postoji poseban, pogrdan termin za ove nacionalnosti, uključujući Srbe i Bosance, 'Čefurji', koji je vrlo živ u diskursu ekstremne desnice. Termin se koristi kako bi naglasio da su članovi ovih zajednica Balkanci, što Hrvati više vole negirati. 
stvo s kršćanskim susjednim zemljama biti gurnuto u pozadinu, a sasvim će novi kršćanski identitet zamijeniti onaj etnički ili naprosto kohabitirati s njim.

Tradicionalno je lice neprijatelja potpuno izmijenjeno. U Europi i Sjevernoj Americi trenutno omraženi Drugi definitivno se ne pojavljuje u svojem tradicionalnom militarističkom obliku, osim kod zanemarivih iznimaka. Novo je lice omraženog 'Drugog' ono imigranta, bilo ekonomskog, bilo političkog. Nestale su opasnosti koje se tradicionalno vežu s vojnom prisutnošću; nacionalni populisti moraju izmisliti i konstruirati pretpostavljenu opasnost koja u zemlju dolazi zajedno sa stranim obiteljima, uključujući onima s djecom.

Ukratko, ako su ove hipoteze istinite, političari i teoretičari suočeni su s promjenom. Tradicionalno je pitanje razlikovanja patriotizma/nacionalizma i kozmopolitizma promijenilo naličje: trenutno je drastična razlika između populističke averzije prema strancima migrantima i velikodušnijih, pravednijih i prihvaćajućih shvaćanja te samaritanske vrste pomaganja. Averzija nasljeđuje neka obilježja tradicionalnog patriotizma visokog profila i nacionalizma, dok prihvaćanje dijeli glavne karakteristike tradicionalnog kozmopolitizma. Pretpostavljam da će se buduće znanstvene analize patriotizma uglavnom usredotočiti na ovo novo i izazovno područje, a s ciljem da se obrati novome razlikovanju i pronađe odnos patriotiz(a)ma u odnosu na njega.

Konačno, populističko razumijevanje 'našeg naroda' ('mi-zajednice') ne uključuje samo nacionalističke mogućnosti, već ide i mnogo dalje od njih. Važan je element promiskuitetni karakter populističkih odluka. Tradicionalno je razlikovanje bilo ono između kozmopolitizma svojstvenog univerzalizmu i nacionalizma svojstvenog partikularizmu. Novina koju je populizam donio je fleksibilnost i podatnost partikularističke opcije: može se odrediti nacionalnošću ili, alternativno, bilo kojom drugom vrstom komunitarno kulturalno-lingvističkim pripadanjem. Može se ujedno razlikovati od drugoga tipične razlikovne klase istoga nivoa: katolici protiv pravoslavaca, kršćani protiv muslimana, itd.

\section{HRVATSKA ZAgONETKA}

\section{(A) Pristupi i Nesuglasice}

Ovaj se odjeljak usredotočuje na odnos između nacionalizma i populizma u Hrvatskoj: pitanje je možemo li njenu suvremenu politiku okarakterizirati kao nacionalni populizam te, ako možemo, koliko je on jak. ${ }^{6}$ Pomalo

16 Zahvalan sam profesorima Bertu Šalaju i Marijani Grbeši, kao i izvrsnom novinaru Borisu Paveliću, s kojima sam raspravio ovo pitanje u Rijeci. 


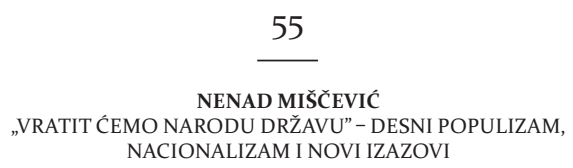

anticipirajući, pitanje je teže nego li se čini, a odgovor je neočekivano nesiguran.

Započnimo onime što je sigurno: Hrvatska je imala povijest žestokog i uspješnog nacionalizma barem od osamdesetih, s etničkim čišćenjem, mnogo žrtava s obje zaraćene strane te, naposlijetku, mnogo nacionalističkog sadržaja upisanog u ideološke osnove nove države. Neprijatelj je bio isključivo jedan, Srbi, premda je bilo nešto vojnog pritiska i nešto počinjenih ratnih zločina i prema bosanskim muslimanima. Antipatija, da ne kažemo mržnja, prema Srbima postalo je jedno od obilježja hrvatskog patriotizma visokog profila. U Hrvatskoj je stoga desni populizam dominantno, zapravo isključivo, patriotsko-nacionalistički. Drugi kulturološki faktori, prije svega vjeroispovijest i jezik, imaju ulogu jedino u nacionalističkom okviru. Primjerice, općenit je antimuslimanski stav proturječan tvrdnjama hrvatskog nacionalizma, prema kojima su bosanski muslimani 'cvijet hrvatskog naroda', a njihova vjera samo slučajna posljedica turskih osvajanja. Razlikovanje između katoličke i pravoslavne vjeroispovijesti ima ulogu samo u kontekstu nacionalističke mržnje prema Srbima. Makedonci, koji su isto pravoslavci, percipirani su kao prijatelji ili barem 'neutralno'. Stoga podatnost komunitarističkih kategorija nadnacionalne kulturološke pripadnosti ne igra nikakvu ulogu, već je ono što je važno etnička nacionalnost ili 'hrvatstvo'. ${ }^{17}$

Vratimo se iz kratkog izleta u povijest. Treba naglasiti da se, u velikoj mjeri zbog pritiska EU, situacija polako smiruje. Ovdje je relevantno pitanje posljedica ove tužne priče, posebice s obzirom na nacionalni populizam. Začuđujuće, ne postoji konsenzus oko odgovora, čak ni među očito nenacionalističkim ili antinacionalističkim autorima. Prepoznajemo dva ekstremna odgovora. Prva je tvrdnja, jako prisutna među novinarima, da Hrvatskom 'vladaju autoritarni populisti' nacionalističkih sklonosti. Stoga Jure Trampuš ustvrđuje da su 'sve susjedne države' Slovenije, a to uključuje i Hrvatsku, 'pod vladavinom autoritarnih populista', dok je Slovenija 'otok slobode' usred ove populističke konstelacije (Trampuš 2018).

Drugi odgovor nude Grbeša i Šalaj (2018b), koji su proveli detaljnu analizu diskursa političara u zadnjem desetljeću te pronašli iznenađujuće malo nacionalnog populizma. Grbeša čak tvrdi da „u Hrvatskoj nema desnog populizma". 18 Moj je vlastiti stav u sredini: manje sam optimističan

17 Preuzimamo ovaj opis rascjepa iz izvrsnog već spomenutog teksta Andrija Henjak, Nenad Zakošek and Goran Čular, “Croatia”, u zborniku, Sten Berglund, Joakim Ekman, Kevin Deegan-Krause, Terje Knutsen, Handbook of Political Change in Eastern Europe (2013).

18 Ona terminom 'desno' označava nacionalizam s mržnjom prema manjinama, a 'nacionalističkim' onaj koji se ne zasniva na mržnji prema manjinama; pitanje realističnosti ove distinkcije zahtijeva diskusiju koja je izvan okvira ovoga poglavlja; za Grbešina stajališta videti njezin intervju za Tportal.hr (2018). 
od Grbeše i Šalaja, no, s druge strane, nisam u stanju prepoznati nijednog autoritarno-populističkog političara među vođama trenutne hrvatske vlade. Valja podsjetiti da je termin 'autoritarni populizam' konceptualizirao Stuart Hall kako bi se referirao na fenomene kao što su 'tačerizam' u Ujedinjenom Kraljevstvu te, kasnije, 'reganizam' u SAD; nijedan hrvatski mogući kandidat nije ni na koji način sličan ovim dvema zvijezdama. Predsjednica, Kolinda Grabar-Kitarović, imala je neke populističke trenutke, te nešto pozitivnih osjećaja prema susjednim populističkim vođama kao što je Orbán, no njoj nedostaje autoriteta. Njezino ponašanje daleko je od autoritarnog te joj nedostaje snažni nacionalistički angažman. Premijer, Andrej Plenković, jedno je desetljeće bio predstavnik Hrvatske pri institucijama EU. Često je bio kritiziran za manjak autoriteta (i za poslušnost Angeli Merkel), a ne za autoritarnost, te je često optuživan da je EU birokrat kojemu nedostaje pravoga patriotizma. Njima dvoma svakako ne pristaje slika autoritarnih populista. ${ }^{19}$

Stranka koja bi bila prikladan kandidat za desni nacionalni populizam je stranka Most. Njezini su članovi imali očito nacionalističke komentare. U vrijeme kada je ovo poglavlje koncipirano, u novinama se odvijala žustra debata o optužbama Nikole Grmoje, prominentnoga člana Mosta, prema kojima je glavni predstavnik srpske manjine u hrvatskom Saboru, Milorad Pupovac, dao skandalozan prešutni pristanak nekim ultrašovinističkim primjedbama srbijanskog predsjednika. Navodni se pristanak sastojao samo od njegove prisutnosti na komemoraciji srpskim žrtvama operacije Oluja hrvatske vojske u kojoj su masakrirani srpski civili. Grmojina je opaska nacionalno-populistička, no ujedno i desna u smislu Grbeše i Šalaja, jer polazi od ekstremne antipatije prema srpskoj nacionalnoj manjini koju predstavlja Pupovac. No, Grbeša i Šalaj tvrde da službeni diskurs Mosta u dvjema izbornim kampanjama, 2015. i 2016, nije sadržavao takve elemente.

[...] naša analiza nije detektirala gotovo nikakvu prisutnost 'opasnih drugih' u diskursu Mostovih vodećih političara. Prisutnost 'opasnih drugih' detektirana je u samo dva od 57 slučajeva (opasni mediji i sudstvo). Očito, nije bilo sistematske stigmatizacije određenih društvenih i ekonomskih aktera koji, uz političke elite, ugrožavaju dobrobit naroda. Nepostojanje 'opasnih drugih' u diskursu Mosta ujedno negira pretpostavku o njegovim predominantno konzervativnim vrijednostima [...] (Grbeša i Šalaj 2018a, 19)

Godinu kasnije situacija je nepromijenjena: „Ispitivanje spominjanja 'opasnih drugih' u 2016. definitivno je potvrdilo da su 'opasni drugi' bili

19 Novinari skloni ovim optužbama obično ih potkrepljuju upućujući nas na nacionalističke ekcese slavnih javnih ličnosti, kao što je Thompson, te s pravom optužuju premijera za nedovoljno reagiranje protiv njih; no ova vrst pasivnosti i manjka autoriteta jedva zaslužuje biti nazvana autoritarnom. 


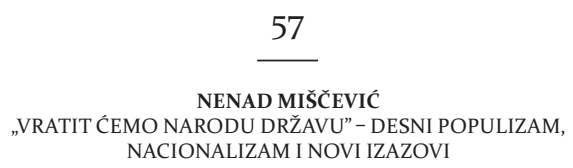

samo rijetko prisutni u Mostovom diskursu. Takve su primjedbe pronađene u samo 4.9\% slučajeva”. (Ibid, 21) Stranka je Most dobila viši rezultat s obzirom na antielitizam (u otprilike pola slučajeva), te nizak rezultat s obzirom na antiprofesionalizam. Nije pokazala posebno nacionalističke stavove. Autori zaključuju da je Most umjerena centristička populistička stranka, te antiestablišmentska reformska stranka. Ako je ovo čitanje Mostovog diskursa točno, onda su primjedbe kao što je Grmojina atipična preuveličavanja, isprovocirana dobrom prilikom za privlačenje pozornosti, a ne tipično mainstream primjedbama karakterističnim za taj diskurs.

Zaključno, Grbeša i Šalaj naglašavaju da njihova analiza nije otkrila prisutnost snažnog, netolerantnog desničarskog populizma. ${ }^{20}$

\section{(в) ZAGONETKA: ZAŠTo HRVATSKA NEMA SNAŽNU DESNU POPULISTIČKU STRANKU?}

Vladajuća je stranka, HDZ (Hrvatska demokratska zajednica), glavni kandidat da bude označena kao nacionalno-populistička. Tadašnji hrvatski disidenti, vođeni bivšim predsjednikom Franjom Tuđmanom, osnovali su je 1989, a službeno registrirali 25. siječnja 1990. Grbeša i Šalaj analizirali su diskurs sljedećih HDZ-ovih izbornih kandidata: Milana Kujundžića (neuspješnog kandidata), Tomislava Karamarka (umjereno uspješnog), te dva vrlo uspješna, Jadranku Kosor (bivšu hrvatsku premijerku, 20092012) i Kolindu Grabar Kitarović (izabranu 2015). Nalazi su im iznenađujući: niti jedan od njih nije se služio agresivno desničarskim diskursom usmjerenim protiv manjina. Kosor i Karamarko nisu govorili populističkim stilom stoga što su govorili u ime vladajuće elite (bez antielitističkog diskursa). Još više iznenađuje da nisu mnogo spominjali narod ili naciju u pozitivnom svjetlu!

Jednako iznenađuje da trenutna predsjednica, Kolinda Grabar-Kitarović, nije 'narod' spominjala na empatičan, pozitivan način više od dva od jedanaest spominjanja toga termina; većina je spominjanja bila neutralna. Kao HDZ-ov predsjednički kandidat, nije se ni distancirala od vladajuće elite. Osim toga, negativan stav prema manjinama nije bio prisutan. Jedini je očito nacionalno populistički predsjednički kandidat, Kujundžić, imao neke antielitne komentare i pozitivne spomene 'naroda-nacije.' Kao što je već spomenuto, potpuno je promijenio retoriku nakon gubitka na izborima.

Slažem se s Grbešom i Šalajem da HDZ sigurno nije agresivno nacionalno populistička stranka, premda su neki vrlo poznati članovi tvrdi nacionalisti. Nalazim da HDZ nije ni nacionalno populistička stranka. Nije dovoljno populistička da bi se brojala kao populistička simpliciter, a njezin 
POLITIČKE PERSPEKTIVE

ČLANCI I STUDIJE

je nacionalizam postao vrlo umjeren, vrlo udaljen od onoga što je Taguieff prikazao kao tipično gledište nacionalno populističkih stranaka. Ako je sve ovo točno suočeni smo sa zagonetkom. Uzimajući u obzir žestoku i agresivno nacionalističku prošlost zemlje, a osobito HDZ-a, kako je moguće da vladajući establišment nije nacionalno populistički ni autoritarno populistički? ${ }^{21}$

Prvo, postoji problem s vertikalnom dimenzijom populizma (narod protiv elita): HDZ je etablirana hrvatska stranka na vlasti, jasan slučaj političke elite, pa bi stoga njihov glasni antielitizam bio percipiran kao obmana. ${ }^{22}$

Drugo, horizontalna je dimenzija (mi protiv drugih) isto preslabo predstavljena u Hrvatskoj: postoji nacionalizam, no nije vrlo prisutan u diskursu državnih službenika (predsjednika i premijera), a nije ni dovoljno sistematičan niti agresivan u diskursu establišmenta u cjelini da bismo ga nazvali nacionalno populističkim. Tipična je suvremena kritika Vlade da nedovoljno reagira protiv javnih nacionalističkih ekscesa (koje čine sportske ili glazbene zvijezde ili ratni veterani), a ne ona da stvarno nacionalistički djeluje.

Sve ovo čini zagonetku dramatičnijom. Složimo se da je vertikalna dimenzija očito preslaba: HDZ je stranka establišmenta, ne postoje jasne alternativne elite, stoga je normalni, populistički, antielitistički smjer vrlo težak za kandidata HDZ-a ili onoga bliskog HDZ-u. Stoga je na strani ponude blokada. Kako bismo dobili jasniju sliku, treba upamtiti da je u Hrvatskoj desni populizam pretežno, zapravo isključivo, patriotsko-nacionalistički. Prema tome, bilo koja desna populistička stranka trebala bi predstaviti patriotsko-nacionalistički program. Kako bi u tome bila uspješna morala bi optužiti političke elite za manjak patriotskog nacionalizma. No što ako je vladajuća stranka već poprilično nacionalistička? Novi populisti morali bi probati kohabitirati s vladajućom strankom, što je točno ono što je učinila umjereno populistička stranka Most. A to nije bilo uspješno.

Već sam spomenuo da je HDZ dovoljno nacionalistički da se obrani od mogućih optužbi populista za izdaju, a nedovoljno nacionalistički da bi bio očito i isključivo nacionalistička stranka. To nam sugerira da odgovor na zagonetku leži u tom umjerenom i državnom nacionalizmu vladajuće stranke, HDZ-a.

Ključni odgovor na zagonetku možemo svesti na HDZ-ovu povijesnu transformaciju iz čisto desne u stranku desnog centra te njegovo približa-

21 U onome što slijedi napustit ću distinkciju Grbeše i Šalaja između nacionalističkog i desnog populizma i vratiti se terminologiji u kojoj se oni smatraju jednim fenomenom.

22 I Grbeša i Šalaj napominju da je vertikalna dimenzija ekstremno problematična, no ne razvijaju nikakvo objašnjenje za fenomen koji su proučavali desetljeće ili duže. M. Grbeša i B. Šalaj (2018b, 233). 
NENAD MIŠČEVIĆ

„VRATIT ĆEMO NARODU DRŽAVU” - DESNI POPULIZAM,

NACIONALIZAM I NOVI IZAZOVI

vanje demokršćanskoj tradiciji. U ideološkom smislu, u početku su vođe HDZ-a opisivali stranku kao desnu, dok je bivši predsjednik Tuđman sam izrekao da je bio inspiriran tačerizmom. Kasnije je stranka sebe opisivala kao demokršćansku stranku desnog centra. No, jedina je službena ideologija, koja je izazvala konflikte devedesetih, bila nacionalizam. Snažno nacionalističke tendencije omekšane su nakon završetka rata. HDZ, sada više upućen na unutarnja politička pitanja, postao je većinom društveno konzervativna stranka.

Razmotrimo sada recentniju situaciju iz dviju perspektiva, one ponude i one potražnje. Prvo, za potencijalnog desničarskog populističkog glasača (sa strane potražnje), najprikladniji kontekst bio bi onaj gdje bi on mogao političke elite optužiti za nedostatak patriotske privrženosti i nacionalizma. 'Narod želi zaštititi vlastiti identitet, a proklete elite su ga izdale!' Kontekst vladavine HDZ-a dramatično je neprikladan za takve optužbe: stranka je stvorila nacionalnu državu, potvrdila svoj patriotizam na stotinama ispita, favorizirala interese etničkih Hrvata u usporedbi s interesima potencijalno najomraženije manjine, Srba, itd. Dovoljno je nacionalistički da onemogući moguće populističke kritike i optužbe. ${ }^{23}$ Ukratko, HDZ je u svoju korist preduhitrio pitanje patriotsko-nacionalističkog sentimenta.

Drugo, iz perspektive političke elite (sa strane potražnje), treba napomenuti da joj je potrebna javna podrška, no da je ujedno odabrala članstvo Hrvatske u Europskoj uniji, svjesna da mnogi njeni glasači članstvo vide kao važnu prednost s obzirom na to da Srbija (još) nije član. Racionalan put za elitu nije populističko eksperimentiranje, već potraga za srednjim putem: što je moguće više ispuniti nacionalistička očekivanja bez odustajanja od proeuropskih stavova. Istina, tijekom svih ovih događaja bilo je nekih više ili manje populističkih epizoda: Tuđman jest odveo svoj nacionalizam do ekstrema, a dva desetljeća kasnije Karamarko je pokušao istu taktiku. No, ove epizode nisu pretvorile HDZ u nacionalno populističku stranku.

Na premijerskoj razini, Tuđmanov je nasljednik bio Ivo Sanader. Njegova se vlada (2003-2009) bavila politikama potrebnim za zadovoljavanje osnovnih kriterija za članstvo u Europskoj uniji, uključujući povratak izbjeglica svojim domovima, obnavljanje kuća oštećenih u ratu, poboljšavanje prava manjina uključivanjem manjinskih predstavnika u Vladu, suradnju s ICTY-jem, te nastavak konsolidacije hrvatske ekonomije.

23 HDZ je dokazao svoj patriotizam kroz svoju kulturnu politiku, primjerice podržavajući kulturne organizacije koje se bave poprilično snažno nacionalističkim politikama (npr. čišćenje hrvatskog jezika od pretpostavljenih 'srpskih' riječi, te njihovo zamjenjivanje izmišljenim riječima arhaičnog prizvuka), kratkoročnim, ali podosta brutalnim čišćenjem intelektualne kaste, izbacivanjem s posla navodno nepatriotskih intelektualaca, itd. Dodatno, HDZ je ugađao hrvatskim ratnim veteranima, koji su prema njemu razvili dugotrajnu i stabilnu odanost. 
Hrvatska je vlada toga doba završila kao ona desnog centra. Ova je konzervativna linija desnog centra idealan srednji put koji ne ostavlja nikakav prostor pobjedi prepoznatljivo populističkih antielitnih ponašanja. Primjerice, trenutna predsjednica, Kolinda Grabar Kitarović, iskazala je podršku Višegradskoj skupini, no više u smislu ekonomske suradnje a ne u smislu podrške specifično desnim političkim odlukama višegradskih zemalja, kao što su Poljska ili Mađarska. Ne treba slijediti Orbána i Kaczyńskije. ${ }^{24}$

Sada bismo trebali spomenuti pravni okvir koji podržava vladavinu prava u Hrvatskoj. ${ }^{25}$ Okvir balansira između nacionalnih interesa i ljudskih prava, posebno manjinskih prava. Preambula Ustava, primjerice, započinje posebno naglašenim sažetkom 'tisuću godina povijesti' koje Hrvatima jamče njihovo povijesno pravo na državnost, ${ }^{26}$ ali tada navodi da je Hrvatska država Hrvata i manjina, te eksplicitno popisuje 22 manjine koje su, zajedno s etničkim Hrvatima, konstituirale državu. Članak 3 Ustava utvrđuje 'nacionalnu ravnopravnost i ravnopravnost spolova' među 'najviše vrednote ustavnog poretka'.

Slično je balansiranje bilo na djelu u kontekstu međunarodne pravde, posebice s obzirom na ratne zločine koje je počinila hrvatska vojska tijekom rata. U svojoj knjizi o ovoj temi Jelena Subotić s pravom tvrdi da „[...] hrvatska opredijeljenost za tranzicijsku pravdu mnogo se godina najbolje može opisati kao jedan korak unaprijed, dva unatrag” (Subotić 2009, 83). Ona objašnjava:

Hrvatska je vlada surađivala većinom selektivno, nevoljko i nedovoljno s Haškim sudom. Pritisci koji su stizali iz ICTY-a, no i iz drugih međunarodnih organizacija i individualnih država, stvorile su duboke podjele unutar hrvatske države te je 'haško pitanje' dominiralo nad unutarnjopolitičkim debatama i suprotstavilo snažne unutarnje interesne skupine jedne protiv drugih.

Ova je bezlična suradnja završila 2005. kada je Hrvatska transferirala posljednjeg optuženika ICTY-a Hagu i time zapravo ispunila svoje obveze prema sudu. (Ibid)

Ravnoteža između političkog i pravnog pretvorila je dominantni nacionalizam u onaj državni desnog centra, koji nije vrlo prikladan za snažnu populističku retoriku. Ponovimo, to ne čini umjereni nacionalizam desnog centra idealnim, niti bliskim idealu. Za moj osobni, poprilično kozmo-

24 Za usporedbu s poviješću srpskog populizma videti doprinos Dušana Spasojevića u Beširević, 2019.

25 Zahvalan sam svome kolegi i prijatelju Miomiru Matuloviću za korisnu diskusiju o ovim pitanjima.

26 Preambula hrvatskog Ustava eksplicitno spominje da se to pravo očituje u „[...] stvaranju hrvatskih kneževina u VII stoljeću; [...] srednjovjekovnoj samostalnoj državi Hrvatskoj utemeljenoj u IX stoljeću; [...] Kraljevstvu Hrvata uspostavljenom u X stoljeću; [...].” 
politski ukus, on je samo manje zlo od svoje neumjerene, isključivo desne varijante, no može biti vrlo koristan protiv porasta populističke prijetnje.

\section{ZAKLJUČAK}

Porast populizma, posebice u kontekstu izbjegličke krize, transformirao je politički okvir Europe, a vjerojatno i šire. Možemo se početi pitati o nedostacima dostupnih formi demokracije: što je pošlo po zlu i zašto? (vidi, primjerice, Isaaharov, 2015). Možemo i primijetiti da je klasični nacionalizam nadomješten „transnacionalnim nacionalizmom” koji krivuda između širih identiteta („kršćanski korijeni Europe“) i onih uskih (hrvatstvo, srpstvo, slovenstvo) na jedan poprilično neprincipijelan, oportunistički način. Teoretičari nacionalizma trebali bi ovu promjenu sagledati kao ozbiljan izazov i usmjeriti se na potrebu novog razumijevanja mogućnosti povezanih s nacionalizmom.

Slični nas izazovi čekaju na suprotnoj strani. Klasični kozmopolitizam usmjeren na daleke narode zamijenila je solidarnost s trenutno potrebitim strancima. Otvoreno je pitanje što je ostalo od stare koncepcije, te što je potrebno preraditi. Ostaje jedno klasično pitanje, no pomalo u pozadini: koja vrsta naddržavnog aranžmana bi mogla blokirati masovne migracije, te stoga pomoći zadržati ekscese antiimigrantskog, desnog populizma? Kako pravednija globalna organizacija može pomoći te, za početak, kako ona može biti implementirana?

\section{LITERATURA}

Albertazzi, Daniele, McDonnell, Duncan. 2015. Populists in Power. London and New York: Routledge. doi: 10.4324/9781315725789

Arditi, Benjamin. 2007. Politics on the Edges of Liberalism Difference, Populism, Revolution, Agitation. Edinburgh: Edinburgh University Press.

Aslanidis, Paris. 2017. "Populism and Social Movements". In. Eds. Kaltwasser, Cristóbal Rovira, Taggart, Paul Ochoa Espejo Paulina and Ostiguy. Pierre. The Oxford Handbook of Populism. Oxford: Oxford University Press. doi: 10.1093/ oxfordhb/9780198803560.013.23.

Besirevic, Violeta (ed.). 2019. New Politics of Decisionism. Hague: Eleven International Publishing.

Blokker, Paul. 2005. 'Populist Nationalism, Anti-Europeanism, Postnationalism, and the East-West Distinction'. German Law Journal, 6 (2):371-389.

Canovan, Margaret. 1981. Populism. New York and London: Harcourt Brace Jovanovich.

Carens, Joseph, 2013, The Ethics of Immigration. New York: Oxford University Press. 
Curren, Randall. 2019. "Patriotism, Populism, and Reactionary Politics since 9.11". In Ed. Sardoc, Mitja. Handbook of Patriotism. Springer. doi: 10.1007/978-3319-30534-9

Čular, Goran. 2004. „Razvoj hrvatskog stranačkog sustava: četiri teze”. U Kregar, Josip, Puljiz, Vlado, Ravlić, Slaven (ur.). Hrvatska - kako dalje? Zadanosti i mogućnosti. Pravni fakultet Sveučilišta u Zagrebu; Centar za demokraciju i pravo Miko Tripalo. 135-150.

Čular, Goran, Henjak, Andrija, Zakošek, Nenad. 2013. "Croatia”. In Eds. Sten Berglund, Joakim Ekman, Kevin Deegan-Krause, Terje Knutsen. Handbook of Political Change in Eastern Europe. Edward Elgar zrd edition, 443-48o.

De Cleen, Benjamin. 2017. "Populism and Nationalism". In Eds. Kaltwasser, Cristóbal Rovira, Taggart, Paul Ochoa Espejo Paulina and Ostiguy. Pierre. Handbook of Populism, Oxford: Oxford University Press. doi: 0.1093/oxfor$\mathrm{dhb} / 9780198803560.013 .18$

Fine, Sarah and Ypi Lea (eds.). 2016. Migration in Political Theory: The Ethics of Movement and Membership. Oxford: Oxford University Press.

Gat Azar, Yakobson Alexander. 2013. Nations: The Long History and Deep Roots of Political Ethnicity and Nationalism. Cambridge: Cambridge University Press.

Gellner, Ernest and Ionescu, Ghita. 1969. "A Spectre is Haunting Europe - the Spectre of Populism”. In. Eds. Gellner, Ernest and Ionescu, Ghita. Populism: Its Meanings and National Characteristics, London: Macmillan.

Gellner Ernest. 1983. Nations and Nationalism. Oxford: Basil Blackwell.

Grbeša, Marijana and Šalaj, Berto. 2018a. 'Populism in Croatia: The Curious case of the Bridge (Most)'. Anali Hrvatskog politikološkog društva. 14:19.

Grbeša, Marijana and Šalaj, Berto. 2018b. Dobar, loš ili zao? Populizam u Hrvatskoj. Zagreb: Tim press.

Henjak, Andrija. 2018. 'Nose li parlamentarni izbori 2015. i 2016. godine promjenu političkih rascjepa u Hrvatskoj?', Društvena istraživanja, 27(3), str. 383-406. https://doi.org/10.5559/di.27.3.01

Issaharov, S. 2015. Fragile Democracies Contested Power in the Era of Constitutional Courts. Cambridge: Cambridge University Press.

Kastoryano, Riva. 2006. "Vers un nationalisme transnational. Redéfinir la nation, le nationalisme et le territoire”. Revue française de science politique, 56 (4): 533553. doi: 10.3917/rfsp.564.0533

MacIntyre, Alsdair. 2002. 'Is Patriotism a Virtue?' In Ed. I. Primoratz. Patriotism, Amherst: Humanity Books.

Merkel, Wolfgang. 2016. „Kozmopolitizam protiv komunitarizma: novi sukob u europskim demokracijama”. Političke perspektive, 6 (3): 73-86. 


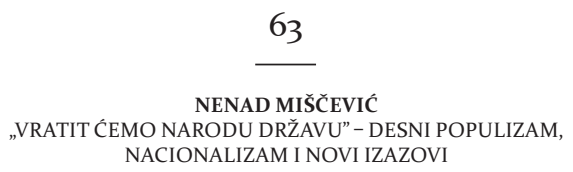

Miller, David. 2007. National Responsibility and Global Justice. Oxford: Oxford University Press.

Miller, David. 2013. Justice for Earthlings: Essays in Political Philosophy. Cambridge: Cambridge University Press.

Miller, David. 2016. Strangers in Our Midst: The Political Philosophy of Immigration. Cambridge, Massachusetts: Harvard University Press.

Moore, Margaret. 2010. "National Commitments and Universal Duties: On the Interrelationship between Domestic and Global Justice". In Eds. Breen Keith and O'Neill, Shane. After the nation? Critical Reflections on Nationalism and Postnationalism. Basingstoke, Hampshire: Palgrave Macmillan.

Mudde, Cass. 2004. “The Populist Zeitgeist”. Government and Opposition, 39 (4): 541-563. doi: 10.1111/j.1477-7053.2004.00135.X

Mudde, Cass. 2007. Populist Radical Right Parties in Europe. Cambridge: Cambridge University Press.

Mudde, Cass. 2017. 'Populism: An Ideational Approach'. In Eds. C.R. Kaltwasser, C., Taggart, P., Espejo, P., \& Ostiguy, P., The Oxford Handbook of Populism. Oxford: Oxford University Press, doi: 10.1093/oxfordhb/97801988o 3560.001.0001.

Mudde Cass and Rovira Kaltwasser Cristóbal. 2017. Populism A Very Short Introduction, Oxford: Oxford University Press

Müller, Jan-Werner. 2016. What is Populism. London: Penguin and University of Pennsylvania Press.

Müller. Jan-Werner. 2017. Što je populizam? Zagreb: TIM press.

Nathanson, Stephen. 1993. Patriotism, Morality, and Peace. London: Rowman \& Littlefield.

Orwell, George. 2000. 'Notes on Nationalism'. Firs. pub. Polemic, London 1945, reprinted in G. Orwell, Essays. London: Penguin.

Pantazopoulos. 'Populism or National-Populism? A Critical Approach to Cas Mudde's Perspective on SYRIZA's Populism'. Telos, 25 March 2016. https://www. telospress.com/populism-or-national-populism-a-critical-approach-to-casmuddes-perspective-on-syrizas-populism/ (accessed 14. 5. 2019).

Rangelov, Iavor. 2013. Nationalism and the Rule of Law: Lessons from the Balkans and Beyond, Cambridge: Cambridge University Press.

Sandel, Michael. 1998. Democracy's Discontent: America in Search of a Public Philosophy, Cambridge, MA: Harvard University Press.

Scruton, Roger. 2006. England and the Need for Nations. London: Civitas-Institute for the Study of Civil Society (2nd ed.)

Spencer, Vicky. 2018. 'Communitarianism' and Patriotism'. In Ed. Sardoč, Mitja. Handbook of Patriotism. Cham: Springer. doi: 10.1007/978-3-319-30534-9_33-1 


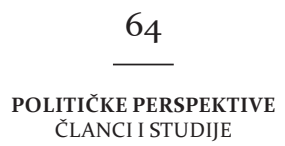

Stelzer, Harald. 2018. 'Communitarianism and Right-Wing Populism'. Conference Presentation at the Philosophy Conference Ethical Issues: Theoretical E Applied. Bled. Slovenia. 4-8 June (on file with author).

Stavrakakis, Yannis. 2004. 'Antinomies of formalism. Laclau's theory of populism and the lessons from religious populism in Greece'. Journal of Political Ideologies, 9(3): 253-267. doi: 10.1080/1356931042000263519

Stavrakakis, Yannis and Giorgios Katsambekis. 2014. 'Left-wing populism in the European periphery: the case of Syriza'. Journal of Political Ideologies, 19 (2): 119142. doi: 10.1080/13569317.2014.909266

Subotić, Jelena. 2009. The Hijacked Justice: Dealing with the Past in the Balkans. Ithaca: Cornell University Press.

Šalaj, Berto. 2012. „Što je populizam?” Političke analize, 3 (11): 55-61.

Taguieff, Pierre-André. 1984. 'La rhétorique du national-populisme [Les règles élémentaires de la propagande xenophobe]'. Mots. Les langages du politique, 9: 113-139.

Taguieff, Pierre-Andre. 1997. "Le populisme et la science politique du mirage conceptuel aux vrais problems”. Vingtième Siècle. Revue d'histoire, 56(4): 4-33. https://www.cairn.info/revue-vingtieme-siecle-revue-d-histoire-1997-4-page4.htm.Taguieff, Pierre-André. 2015. La revanche du nationalisme: Néopopulistes et xénophobes à l'assaut de l'Europe, Paris: Presses Universitaires De France (accessed 14. 5. 2019).

Taguieff, Pierre-André. 2017. Osveta nacionalizma: Neopopulisti i ksenofobi u napadu na Europu. Zagreb: TIM press.

Tudoroiu, Theodor. 2018. Brexit, President Trump, and the Changing Geopolitics of Eastern Europe. London: Palgrave Macmillan.

Walzer, Michael. 1989. 'Nation and Universe', The Tanner Lectures on Human Values. Brasenose College, Oxford University. https://tannerlectures.utah.edu/_ documents/a-to-z/w/walzergo.pdf (accessed 14. 5. 2019).

Walzer, Michael. 1992 What It Means to Be an American, New York: Marsilio Publishers.

\section{MREZNE STRANICE}

Bujica 2019. Mrziteljima Hrvatske preglasna su crkvena zvona! Gost: Hrvoje Zekanović 13. 5. 2019. https://www.youtube.com/watch?v=cXCIkSWPibU (pristup 14. 5. 2019)

Centre for Brexit Studies. Patriotism and Populism. https://www.bcu.ac.uk/centrefor-brexit-studies/projects/patriotism-and-populism. (accessed 15. 9. 2019).

Hervardi.com. Hervard. www.hervardi.com/kdo_smo.php (accessed 14. 5. 2019). 


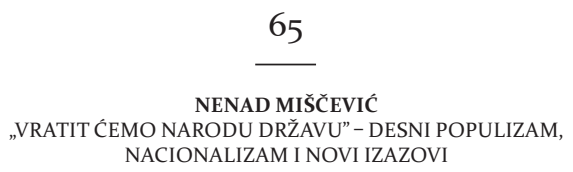

Jutarnji.hr. 2015. „Globusov okrugli stol - Populizam u Hrvatskoj. Populizam je znak bolesti naše demokracije”, 25. 10. 2015. http://izbori.jutarnji.hr/globusov-okrugli-stol-ljevica-u-hrvatskoj-i-europi-populizam-je-znak-bolesti-nasedemokracije-socijaldemokracija-nema-odgovor-na-ekonomsku-krizu/ (pristup 14. 5. 2019).

Narod.hr 2018. „Dr sc. Hrvoje Pende: Marrakech kao peta faza manipulacije - o čemu se u stvari radi?”, 6. 12. 2018. https://narod.hr/hrvatska/dr-sc-hrvoje-pende-marrakech-kao-peta-faza-manipulacije-o-cemu-se-u-stvari-radi (pristup 14. 5. 2019).

Narod.hr 2019. Marijo Popović: „Neka stranka 'Pametno' ustupi svoje prostorije muslimanskoj zajednici za molitvene rituale", 25. 4. 2019. https://narod.hr/hrvatska/marijo-popovic-neka-stranka-pametno-ustupi-svoje-prostorije-muslimanskoj-zajednici-za-molitvene-rituale (pristup 14. 5. 2019).

Net.hr 2018. Emisija Velimira Bujanca pod istragom. 19. 11. 2018. https://net.hr/danas/hrvatska/emisija-velimira-bujanca-pod-istragom-zbog-uzasnog-ispada-ubujici-u-problemu-je-sest-lokalnih-televizija/ (pristup 14. 5. 2019).

Novilist.hr 2018. Intervju Jasmina Klarića s Ivanom Pernarom, "IVAN PERNAR OTKRIVA PLAN ŽIVOG ZIDA 'Napustit ćemo EU i prestati vraćati vanjski dug”” 15.1.2018. http://www.novilist.hr/Vijesti/Hrvatska/IVAN-PERNAR-OTKRIVAPLAN-ZIVOG-ZIDA-Napustit-cemo-EU-i-prestati-vracati-vanjski-dug?meta refresh=true (pristup 14. 5. 2019).

Tportal.hr 2018. Maja Šurina. "Marijana Grbeša: Živi zid su populisti, Most je čudnovat, no u Hrvatskoj ipak nema desnog populizma”, 29. 4. 2018. https://www. tportal.hr/vijesti/clanak/marijana-grbesa-zivi-zid-su-populisti-most-je-cudnovat-no-u-hrvatskoj-ipak-nema-desnog-populizma-foto-20180429 (pristup 14. 5. 2018).

Trampuš, Jure. 2018. 'Nevarna igra', Mladina, 2.8.2018. https://www.mladina. si/186761/nevarna-igra/ (pristup 14. 5. 2019).

\section{SUMMARY}

\section{"We will give Back the State to the People": Right-Wing Populism, Nationalism and New Political Challenges}

The topic of the paper is right-wing populism, strong and widespread throughout the Northern Hemisphere; although the focus is on Croatia and its closest neighborhood. First, the author defines populism and then considers its relationship with its closest phenomena, nationalism, and patriotism. An interesting puzzle about Croatia is the absence of strong, clearly populist parties, despite a strong nationalist orientation in the electoral base; the simplest explanation is that the strongest party, HDZ (Croatian Democratic Union) has managed to take on 
POLITIČKE PERSPEKTIVE

ČLANCI I STUDIJE

important topics of right-wing populism while still preserving the form and ideology of parliamentary democracy. How stable this solution is will be seen in the future. The rise of populism has changed the frame of political contestation in our country and in the world; proponents of opposing political standpoints must now rethink the assumptions of their political action and offer new solutions.

KEYWORDS: populism, patriotism, national-populism, political cleavages. 